\title{
Education Relations, Number of Children and Acceptance of KB Information with Pregnancy Due to Unmet Need KB in Pregnant Mother in Binjai Health Center City In 2019
}

\author{
Syawalina, Heru Santosa, Sri Rahayu Sanusi \\ Faculty of Public Health, University of Sumatera Utara, Indonesia \\ syawalina.amkeb@gmail.com
}

\begin{abstract}
Pregnancy control and regulation is one of the ways to suppress the population in Indonesia through the family planning $(K B)$ program. However, family planning programs in Indonesia still have problems, one of which is the high number of unmet need for family planning in Indonesia. 5 sub-districts in the City of Binjai showed that the District of Binjai Kota which had the highest number of unmet need for family planning was $18.27 \%$. The purpose of this study was to analyze the Relationship of Education, Number of Children and Acceptance of Family Planning Information with Pregnancy Due to Unmet Need for KB in Pregnant Women in Binjai City Health Center in 2019. The method of this study used a cross sectional sample of 113 pregnant women in December 2018 - August 2019 at the Binjai City Health Center. Data were collected by interview using a questionnaire. Based on the results of the study note that out of 113 pregnant women there were 57 people (50.4\%) who became pregnant as a result of Unmet Need KB. Variables related to Pregnancy Due to Unmet Need for KB are the number of children $(p=0.024)$ and the receipt of KB information $(p=0.001)$. The results of multiple logistic regression showed that respondents who had 1-2 children and did not receive family planning information had a probability of suffering from pregnancy due to unmet need for birth control by 57.8\%. The suggestion for this research is that health workers pay more attention to those who have 1-2 children who are motivated to participate in the family planning program and ask pregnant women to ask health workers before using family planning tools as clearly as possible so that they are expected to be able to reduce the reasons for unmet need for family planning.
\end{abstract}

Keywords: determinant factors; pregnancy due to unmet need for $k b$

\section{Introduction}

The explosion in population growth in developing countries that continues to increase is a big problem faced especially for Indonesia. Indonesia is the fourth most populous country after China, India and the United States. Controlling and regulating pregnancy is one way to suppress the world's population. According to the BKKBN (National Population and Family Planning Agency) pregnancy is a process that begins with the release of a mature egg in the fallopian tubes which then meets with sperm, then both of them merge to form cells that will grow. Unwanted pregnancy can worsen the health, social and psychological life of the mother and baby are also very associated with high abortion rates, and pregnancy with 4 too is an ideal pregnancy because too many, too young, too old, and too close will greatly increase risk of complications so it greatly contributes to increasing MMR (PUSDATIN RI Ministry of Health, 2013).

The government's effort in overcoming this pregnancy problem is through family planning (KB) programs. Law No. 52/2009 concerning population development and family development states that family planning is an effort to regulate child birth, distance and ideal age of birth, regulate pregnancy through promotion, protection and assistance in accordance with reproductive rights to create quality families (PUSDATIN Ministry of Health Republic of Indonesia, 2013).

The family planning program has been proven to reduce fertility rates, which is based on the results of the 2012 IDHS survey, the national Total Fertility Rate (TFR) of 2.6 children per woman decreased to 2.4 children per woman in the 2017 IDHS. Meanwhile, North Sumatra Province itself is based on In the 2012 IDHS, the Total Fetility Rate (TFR) of 3.0 children per woman and also 
decreased in the 2017 IDHS, by 2.9 children per woman. However, this does not mean that the population problem is over and the family planning program has not yet achieved maximum results because the TFR nationally and the province of North Sumatra are still far higher than the national TFR target of 2.1 .

One of the obstacles in achieving success in the family planning program in Indonesia is the high number of unmet need for family planning in Indonesia. According to the Indonesian Ministry of Health in 2016 the number of unmet need (EFAs who postpone pregnancy or do not want additional children but do not participate in the KB program) in Indonesia amounted to $12.77 \%$ and decreased $11 \%$ in the 2017 IDHS. Then, in North Sumatra province in 2015 amounted to $16.22 \%$ decreased to $14.86 \%$ in 2016 (Profile of the Republic of Indonesia Ministry of Health, 2015 and 2016). Although the number of unmet need for family planning in North Sumatra has declined, it is also still far higher than the national rate.

Whereas in the City of Binjai itself in 2015 it was $6.1 \%$ and decreased in 2017 by $5.9 \%$ (Health Profile of Binjai City, 2015 and 2017. In 2018 it increased again by 13.39\% (BKKBN Binjai City, 2018) The number is still higher than the national rate where the city of Binjai should be able to reach a more optimal level because in terms of the condition of the region it is very easy to get information and access to health services.

Meanwhile, the number of unmet need for KB in 5 districts of Binjai City in 2018 was North Binjai Sub-district by $11.03 \%$, Binjai Kota Sub-district by $18.27 \%$, West Binjai Subdistrict by $15.12 \%$, East Binjai Sub-district by $12.33 \%$ and South Binjai Sub-district by $14.01 \%$ (BKKBN Binjai City, 2018). In the 5 sub-districts in the City of Binjai it shows that the District of Binjai Kota has the highest number of unmet need for family planning.

Some factors that have a relationship with the occurrence of unmet need are factors of age, education, history of contraception, employment, income and husband's support p-value <0.05, (Resta 2016). Delbiso's research, 2014 entitled "Correlates of Unmet Need for Contraception in Ethiopia" also shows that age, level of education, number of children and religion correlate significantly with unmet need for family planning. According to Suseno's research, 2014 with the title "Factors influencing Unmet Needs for Family Planning in the City of Kediri" Factors that significantly influence unmet need are education, income, status of contraceptive use, women's knowledge for contraception, and husband's consent ( $p<0.05)$.

Education is one that influences the incidence of unmet need for family planning according to Porouw's research (2015) finding mothers with low education have a lack of understanding of the information received, one of them is information about family planning, so the chances of mothers with less education will get higher unmet need for family planning. There is a significant relationship between mother's education and unmet need for family planning (Unmet Need) in Sipatana District.

Research by Usman, Masni and Arsin (2013) found that the number of children is a variable that can increase the occurrence of unmet need for family planning that can be at risk of unwanted pregnancy with a $\mathrm{p}$ value $=0.031$ ( $\mathrm{p}<0.05$ ). Likewise, the 2016 (Huda) research out of 7 variables (age, education, income, number of children, knowledge, husband's support, and attitude) studied only 1 variable, namely the variable number of children with $\mathrm{p}$ value $=$ $0.02(\mathrm{p}<0,05)$ has a significant relationship with the Unmet Need kb.

The results of research conducted by Nanlohy (2017) by obtaining a value of $p=0.035$ ( $\mathrm{p}<0.05$ ), thus Ho was rejected and Ha was accepted. This shows that there is also a relationship between the reception of family planning information and the unmet need for family planning in Panakkukang, Makassar City.

Research results in Nigeria show that of 356 respondents, there were 98 respondents having unwanted pregnancies, and $76 \%$ of unwanted pregnancies were caused by not using contraceptives, (Bongaarts, 2009). 
Based on secondary data from the City Binjai Community Health Center there were 127 pregnant women in December 2018 - January 2019. Seen from the data of the visit of pregnant women there were 79 multigravida grande pregnant women. Nearly more than half the number of pregnant women is multiparous grande. Then the researchers also asked a number of questions to the health workers and 5 pregnant women who visited the Binjai City Health Center. They said the reason why they got pregnant again was because they did not use birth control and experienced failure in the use of the contraception used. Some of them are still found by mothers who do not use contraception to prevent pregnancy (unmet need for family planning). While Binjai is an urban area that is very easy to access health services, there are still numbers of unmet need for family planning. Based on that, we want to know the relationship between education, number of children and acceptance of family planning information with pregnancy due to unmet need for family planning for pregnant women at the Binjai city health center in 2019.

The purpose of this study was to analyze the Relationship of Education, Number of Children and Acceptance of KB Information with Pregnancy Due to Unmet Need for KB in Pregnant Women in Binjai City Health Center in 2019. This research is expected as information for Public health center in an effort to improve family planning services, especially women with unmet need for family planning which affects pregnancy.

\section{Method}

This type of research uses a cross sectional research method. The sample in this study was the entire population of 113 pregnant women respondents who visited the Binjai Kota Health Center at the time of data collection. The independent variable of this research is education, number of children and acceptance of family planning information and the dependent variable is pregnancy due to unmet need for family planning. Data were collected by interview using a questionnaire. Data analysis is univariate analysis, bivariate analysis and multivariate analysis.

\section{Result and Discussion}

The results of the univariate analysis were carried out to see the frequency distribution of education, the number of children and pregnancies due to unmet need for family planning based on table 1, it is known that of 113 respondents The education variable is known that the majority of respondents are highly educated as many as 82 people (72.6\%). In the variable number of children it is known that the majority of respondents have the number of children 1 and 2, as many as 71 people $(62.8 \%)$. In the variable of $\mathrm{KB}$ information acceptance it is known that the majority of respondents received information about $\mathrm{KB}$, which is 86 people $(76.1 \%)$. In the pregnancy variable due to unmet need for family planning, it is known that the majority of respondents experienced pregnancy due to unmet need for family planning, namely as many as 57 people $(50.4 \%)$.

Table 1. Distribution of Education Frequency, Number of Children and Pregnancy due to unmet need for family planning at Public health center Binjai Kota 2019.

\begin{tabular}{lll}
\hline Characteristics of Respondents & $\mathbf{n = 1 1 3}$ & $\mathbf{\%}$ \\
\hline Education & & \\
Low & 31 & 27,4 \\
High & 82 & 72,6
\end{tabular}




\begin{tabular}{lcc} 
Number of children & & \\
$\geq 3$ & 42 & 37,2 \\
1 and 2 & 71 & 62,8 \\
Receiving KB Information & & \\
No & 27 & 23,9 \\
Yes & 86 & 76,1 \\
Pregnancy Due to Unmet Need for KB & & \\
Yes & 57 & 50,4 \\
No & 56 & 49,6 \\
\hline
\end{tabular}

The results of the bivariate analysis were carried out to see the relationship between education, number of children and receipt of family planning information with pregnancy due to unmet need for family planning for pregnant women at the Binjai Kota Health Center with chi-square test based on table 2 , it is known that the analysis of the relationship between education and pregnancy due to unmet need for family planning using the Chi-Square test $\mathrm{p}$ value $=0.878(\mathrm{p}>0.05)$ so that it can be concluded that there is no relationship between education and pregnancy due to unmet need for family planning. The results of this study are in line with research by Sariyati, Mulyaningsih \& Sugiharti (2015) where the results of the study show that there is no significant relationship between wife's education and unmet need events with $\mathrm{p}$-values of $0.057>\alpha(0.05)$. This is because a person already has knowledge of how to prevent pregnancy naturally so they are willing to use modern contraception or use contraception.

In line with Huda's research (2016) there is no relationship between education and the unmet need for family planning, usually unmet need for family planning in Dadapsari village. The education of respondents in Dadapsari Village is mostly of high school education, so it can be said that the education of secondary respondents means that the possibility of the ability to receive information, especially on receiving information about family planning is still classified as medium or sufficient.

The results of the analysis of the relationship of the number of children with pregnancy due to unmet need for KB using the Chi-Square test obtained $p$ value $=0.024(p<0.05)$ so it can be concluded that there is a relationship between the number of children with pregnancy due to unmet need for KB. The results of this study are in line with the results of the Astuti \& Ratifah study (2014) showing that primiparous parity has the highest number of 33 respondents $(54.10 \%)$ and the lowest is grandemultipara parity of 3 respondents $(4.92 \%)$. The number of children influencing someone in using contraception. For respondents who have only had one child the reason for not using contraception is because they want to add more children. Whereas for other respondents the reason for wanting to add children is because they want to have a son. Also strengthened by the results of Suryaningrum's research (2017). There is a significant relationship between parity and unmet need in EFA in Ngupasan Kelurahan 2017.

The results of the analysis of the relationship between the reception of $\mathrm{KB}$ information with pregnancy due to unmet need for KB using the Chi-Square test obtained $\mathrm{p}$ value $=0.001$ ( $p>0.05$ ) so that it can be concluded that there is a relationship between receiving $\mathrm{KB}$ information with pregnancy due to unmet need for KB. The results of this study are in accordance with Kartika's (2015) research, it is known that the distribution of respondents is not hampered in accessing information. The information access variable indicates an influence on the unmet need event. someone who is positive about family planning will receive a good family planning program so that he can receive information related to the planning program and place of service. Conversely, if someone is negative about family planning, it will be difficult to receive information about family planning. The limited information obtained will make a 
person unable to accept family planning programs. In line with Husnah's research (2011) in Makassar City, there was a relationship between receiving information about family planning and the unmet need incident. Respondents who have received good information about family planning understand better the importance of using birth control for maternal health.

Table 2. Relationship of Education, Number of Children and Acceptance of KB Information with Pregnancy due to Unmet Need for KB in Public health center Binjai Kota 2019.

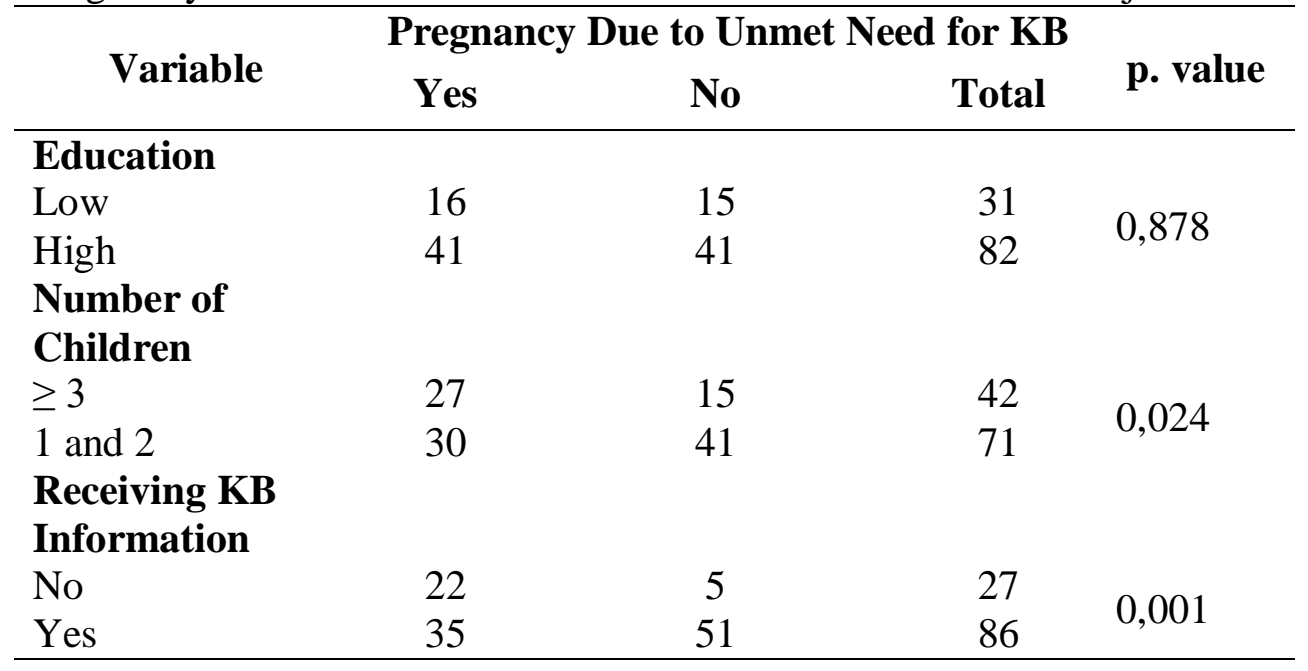

The results of multivariate analysis in this study used a logistic regression test. After bivariate analysis of all independent variables, the independent variables are entered into multivariate analysis with criteria if they have a $p$ value of $<0.25$ and become an important variable in this study. Multivariate results showed that the variable number of children had the largest Exp. B value, namely 3,278, meaning that in the study the variable number of children 3,278 times affected pregnancy due to unmet need for family planning. It is assumed that there is a unmet need for pregnancy in terms of spacing the child or delaying the pregnancy. Mothers actually still want to add more children but not now, but mothers are reluctant to use birth control because of the possibility of fearing fertility will be difficult to return when I want to have more children.

Table 3. Results of Multivariate Logistic Regression Analysis.

\begin{tabular}{lccc}
\hline \multicolumn{1}{c}{ Variable } & Exp. & B & P \\
\hline A constant & 3,380 & 1,218 & 0,016 \\
A number of children & 3,278 & 1,187 & 0,007 \\
Receiving KB Information & 0,124 & $-2,089$ & 0,000 \\
\hline
\end{tabular}

In line with Afiah's research, Darmayanti \& Megasari (2017) found from the results of multivariate analysis that there was a relationship between parity and unmet need for family planning, PUS women with parity $\leq 2$ were 2.5 times more likely to become unmet need for KB compared to PUS women with parity $\geq 3$. Research on the Equator, Baroya \& Wati (2014) in Klabang Subdistrict, Bondowoso Regency shows that there is also a relationship between the number of living children and unmet need for family planning. Likewise with the results of this study indicate that there is an influence of the Parity factor with the unmet need for family planning events. Unmet KB needs can occur at low parity or high parity. There are some couples of childbearing age wanting to postpone pregnancy, spell out or terminate pregnancy but do not 
use contraception on the grounds of fear of side effects if using contraception and if using contraception is afraid if fertility returns not immediately. The number and sex of living children also has a large influence on the acceptance of the Family Planning method (Wahyuni \& Verawati 2019).

\section{Conclusion}

The dominant variable or the most influential factor on pregnancy due to unmet need for family planning is the number of children. Where the number of children 3,278 times affects pregnancy due to unmet need for family planning at the Binjai City Public Health Center.

Suggestions for health workers at the City Binjai Public health center, especially those in charge of $\mathrm{MCH}$ and health cadres, are advised to further improve their ability to provide contraception services including counseling, and personal relationships with prospective acceptors, especially to mothers who are still reproductive and sexually active and who have a number of children $1-2$. Paying attention to pregnant women who have 1-2 children where at the time of counseling ANC examination also provides an explanation of contraception so that later after giving birth are willing to use contraception even though the mother actually wants more children but should spread from the previous child to reduce the health impact because it is too often give birth. Pregnant women are also able to make better use of information about the Family Planning program provided by health service providers (Health community center, helper center, and community Health centers) in the form of direct counseling or through posters, pamphlets, or books. Information can also be obtained from print and electronic media.

\section{References}

Afiah., Darmayanti, I. P., \& Megasari, M. (2017). Faktor-Faktor Yang Berhubungan dengan Kejadian Unmet Need Kb Pada Perempuan Pasangan Usia Subur (Pus). Universitas Pahlawan Tuanku Tambusai, 1(2), 10-14. Diakses dari https://journal.universitaspahlawan.ac.id/index.php/doppler/article/view/134

Astuti, E., \& Ratifah. (2014). Faktor-Faktor Yang Mempengaruhi Wanita Usia Subur (Wus) Tidak Menggunakan Alat Kontrasepsi, 5(2), 99-108. Diakses dari http://ojs.akbidylpp.ac.id/index.php/Prada/article/download/108/98

BKKBN. (2013). Unmet Need dan Kebutuhan Pelayanan KB di Indonesia, Puslitbang KB dan Kesehatan Reproduksi. Analisa Lanjut SDKI 2012. BKKBN. Jakarta

BKKBN, (2018). Survei Demografi dan Kesehatan Indonesia 2017, Jakarta.

Bongaarts, J., \& Sinding, S.W. (2009). 'A respon to critics of family planning programs' international perspectives on sexual and reproductive health Jornal, 35(1), 1.

Huda, A. (2016). Faktor-Faktor yang Berhubungan dengan Kejadian Unmet Need Keluarga Berencana di Pukesmas Bandarharjo Kecamatan Semarang Utara (Tesis, Universitas Muhamadiyah Semarang). Diakses dari http://repository.unimus.ac.id/id/eprint/24

Kartika, D., \& Dwi, W., (2015). Faktor Yang Memengaruhi Unmet Need Keluarga Berencana. E-Journal of Biometrika dan Kependudukan, 4(1), 70-75. Diakses dari http://repository.unair.ac.id/23848/

Katulistiwa, R., Baroya, N., \& Wati, D.M. (2014). Determinan Unmet Need KB Pada Wanita Menikah di Kecamatan Klabang Kabupaten Bondowoso. E-Journal of Pustaka Kesehatan, 2(2), 277-284. Diakses dari https://jurnal.unej.ac.id/index.php/JPK/article/view/1786/1465

Kementrian Kesehatan Republik Indonesia. (2016). Profil Kesehatan Kota Medan 2015. Diakses 
http://www.depkes.go.id/resources/download/profil/PROFIL_KAB_KOTA_2015/1275 _Sumut_Kota_Medan_2015.pdf

Kusika, S. Y. (2018). Pengetahuan Dan Dukungan Suami Dengan Kejadian Unmet Need Keluarga Berencana Pada Pasangan Usia Subur di Wilayah Public health center Biromaru Kabupaten Sigi. E-Jurnal Homepage, 4(1), 46-50. Diakses dari http://jurnal.poltekkesmamuju.ac.id/index.php/m/article/download/64/53/

Nanlohy, S., (2017). Determinan Kejadian Unmet Need Keluarga Berencana Di Kecamatan Panakkukang Kota Makassar (Skripsi, Universitas Hasanuddin). Diakses dari http://repository.unhas.ac.id/handle/123456789/24362

Parouw, H. S., (2015). Faktor- Faktor yang berhubungan dengan kebutuhan Keluarga Berencana yang tidak terpenuhi (unmet need) di Kecamatan Sipatan Gorontalo. Diakses dari http:// ejournal. unsrat. ac. id/ index. php/ jikmu/ article/ download/ 7454 /7128

Resta, L. R., (2016). Faktor-faktor yang mempengaruhi Unmet Need pada Pasangan Usia Subur (Pus) Di wilayah kerja Public health center Sokaraja Ii Tahun 2016. (Skripsi, Fakultas Ilmu Kesehatan Universitas Muhammadiyah Purwokerto). Diakses dari http://repository.ump.ac.id/4828/1/LIA\%20PRI\%20RESTA\%20COVER.pdf

Sariyati, S., Mulyaningsih, S., \& Sugiharti, S. (2015). Faktor yang Berhubungan dengan Terjadinya Unmet Need KB pada Pasangan Usia Subur (PUS) di Kota Yogyakarta. EJurnal Ners and Midwifery Indonesia, 3(3), 123-128. Diakses dari https://researchgate.net/publication/307445010_Faktor_yang_Berhubungan_dengan_Te rjadinya_Unmet_Need_KB_pada_Pasangan_Usia_Subur_PUS_di_Kota_Yogyakarta

SDKI (survei demografi dan kesehatan indonesia). (2012). Angka Fertiliti Rate (2012). Jakarta. Diakses

dari https://www.google.co.id/url?sa=t\&rct=j\&q=\&esrc=s\&source=web\&cd=1\&cad=rjauact =8\&ved=0ahUKEwj9tsq8rdPJAhXEc44KHSPpCfsQFggbMAA\&url=http $\% 3 \mathrm{~A} \% 2 \mathrm{~F} \% 2$ Fchnrl.org\%2Fpelatihan-demografi\%2FSDKI 2012.pdf\&usg=AFQjCNGEiZGaA_NsS93y53ShDFEqufsazQ\&sig2=6QKGrrZqR6wV bVqKuZioXg

SDKI (survei demografi dan kesehatan indonesia). (2017). Angka Fertiliti Rate dan Unmet Need KB (2017). Jakarta. Diakses dari https://www.scribd.com/document/376062145/Survei-Demografi-Dan-KesehatanIndonesia-2017

Suryaningrum, R. (2017). Faktor - faktor yang berhubungan dengan kejadian Unmet Need pada Pasangan Usia Subur (PUS) di Kelurahan Ngupasan Yogyakarta:Fakultas Ilmu Kesehatan. Universitas 'Aisyiyah Yogyakata (Naskah Publikasi, Fakultas Ilmu Kesehatan Universitas 'Aisyiyah Yogyakarta). Diakses dari http://digilib.unisayogya.ac.id/2693/1 /NASKAH\%20PUBLIKASI.pdf

Suseno, M. R., (2011). Faktor-faktor yang berpengaruh terhadap keluarga berencana yang tidak terpenuhi (Unmet Need for Family Planning) di Kota Kediri. E-Journal of Kebidanan Panti Wilasa, 2(1). Diakses dari http://ejurnal.akbidpantiwilasa.ac.id/index.php/kebidanan/article/viewFile/12/11

Usman, L. (2013). Factor associated with the incidence of unmet need KB on Pussy against unwanted pregnancy. Gorontalo (Tesis, FKM Makasar). Diakses dari http://pasca.unhas.ac.id/jurnal/files/7a881f4153e2277f2649f6e250a5c961.pdf

Wahyuni, K. N., \& Verawati, B. (2019). Determinan Kejadian Unmet Need di Kecamatan Ngemplak Kabupaten Sleman Yogyakarta Determinant Of Unmet Need Condition In Ngemplak, Sleman, Yogyakarta.. E-Jurnal Pustaka Kesehatan, 17(1), 52-61. doi : https://doi.org/10.30787/gaster.v17i1.350. 